Mal J Nutr 25(1): 59-67, 2019

\title{
Prevalence and factors affecting food insecurity among university students in Pahang, Malaysia
}

\author{
Wan Azdie Mohd Abu Bakar ${ }^{1}$, Shahidah Ismail ${ }^{1}$, Suriati Sidek ${ }^{2}$ \&ozlin Abdul \\ Rahman $^{3}$ \\ ${ }^{1}$ Department of Nutrition Sciences, International Islamic University Malaysia, Pahang, \\ Malaysia; ${ }^{2}$ Department of Psychology, International Islamic University Malaysia, \\ Pahang, Malaysia; ${ }^{3}$ Department of Physical Rehabilitation Science, International \\ Islamic University Malaysia, Pahang, Malaysia
}

\begin{abstract}
Introduction: Food insecurity exists whenever people are unable to access sufficient food at all times for an active and healthy life. University students are a potentially vulnerable group of people to face food insecurity. This study aimed to identify the prevalence and determinants of food insecurity among a population of university students in Kuantan, in the state of Pahang. Methods: Food security status was identified using the United States Adult Food Security Survey Module (USAFSSM). Factors, which include demographic background, spending expenditure pattern and time constraints, were assessed. A total of 316 students were selected through stratified random sampling throughout six faculties of the International Islamic University Malaysia, of whom 307 successfully completed the survey. Results: The result shows that $54.4 \%$ of the students were experiencing food insecurity, from which $32.9 \%$ were sub-categorised as low food security and $21.5 \%$ as very low food security. Food insecurity was found to be significantly associated with time constraints $(p<0.05)$, spending on books $(p<0.05)$, miscellaneous items $(p<0.05)$, parents' income $(p<0.001)$ and scholarship type $(p<0.001)$. Conclusion: Apart from the high incidence of food insecurity among the students, time and financial affordability appeared to be critical concerns in this study. Since food insecurity has become a significant issue with university students, it should be addressed and prioritised by the relevant authorities.
\end{abstract}

Keywords: Food insecurity, students, food security status

\section{INTRODUCTION}

The importance of food supply was first highlighted by Food and Agriculture Organization (FAO) and the US Department of Agriculture (USDA) when most of the world's communities were experiencing a global food crisis. Various efforts have been made in formulating the tools needed to measure food insecurity. Early direction was concentrated on the volume and stability of food supplies (United Nations, 1975). This coverage was expanded to include access to available supplies of food by vulnerable people, which in turn requires supply and demand to be balanced. In 1996, the World Food Summit stated that "food security exists when all people, at all times, have physical and economic access to sufficient, safe and nutritious 
food that meets their dietary needs and food preferences for an active and healthy life" (Palmer \& Groppo, 2002). The process of understanding food security and the means to achieve it is still an ongoing debate worldwide, as it is a multi-dimensional and complex matter (Adeyeye, 2017; Norhasmah, Zalilah \& Asnarulkhadi, 2010).

The disruption of optimal development have been associated with food insecurity (Alaimo, Olson \& Frongillo, 2002; Cook et al., 2004). Besides physical or physiological effects, Ramsey et al. (2011) reported that children living in food-insecure households were known to experience emotional problems and behavioural disorders. Furthermore, physiological and psychological changes resulting from nutrient deficiencies as an outcome of food insecurity may result in increased frequency of illness among children and therefore decreased participation in school and activities (Alaimo, Olson \& Frongillo, 2001; Diette et al., 2000).

Various findings have also reported that childhood food deprivation is associated with morbidity and mortality in adulthood in a range of diet-related causes such as cardiovascular diseases, type 2 diabetes and some cancers (Ness et al., 2005; Van Der Pols et al., 2009; Wright et al., 2001). Che \& Chen (2001) and Vozoris \& Tarasuk (2003) agree in their studies that individuals living within food insecure households were at a higher risk of developing diabetes mellitus, heart disease and other chronic conditions. In the last decade, food insecurity has also been associated with obesity, making it higher as a public health concern (Pan et al., 2012; Roselawati et al., 2017).

Food insecurity occurs not just in low- and middle-income countries. Pockets of food insecurity also exist in developed countries. In Malaysia, a study conducted by Shariff \& Khor
(2005) among 200 rural women reported that $42.0 \%$ were food secure, $14.0 \%$ household-food insecure, $9.5 \%$ individual-food insecure and $34.5 \%$ suffered child-hunger. Another study done among urban welfare recipient households in Hulu Langat in the state of Selangor, Malaysia, disclosed that $26.3 \%$ of the households were food secure, while $39.8 \%$ experienced moderate food insecurity, and $34.0 \%$ severe food insecurity (Norhasmah et al., 2012). A survey conducted in the district of Kuantan revealed that $77 \%$ of the households experienced food insecurity (Roselawati et al., 2017). The Malaysian Adult Nutrition Survey (MANS), which was a nationwide study, discovered that the prevalence of food insecurity in terms of insufficient food quantity was $24.9 \%$, while $21.9 \%$ reported reduction of meal sizes due to financial constraints (IPH, 2014).

Food insecurity has many consequences. It causes physical and mental health problems, and reduces academic achievements. Furthermore, its long term consequences not only affect the life choices of individuals and households, but also contributes additional burden to the health care system of the country. Given the likely association between chronic diseases, food insecurity and academic accomplishments, improving food security may have potential role in improving students' grade achievement.

While research on food security in the Malaysian context has been undertaken, the extent to which it exists among university students remain largely unexplored. A study of higher learning institutions done by Sulaiman, Md Jusoh $\&$ Ab Razak (2013) reported that $67.1 \%$ of the students faced food insecurity. However, the report mainly discussed coping strategies and the consequences of food insecurity, not its determinants. While many studies have looked at the 
prevalence and the consequences of food insecurity, few have looked at the influencing factors and determinants of food insecurity. The objective of this study was to investigate the food security status and possible determinants of food insecurity among university students in Kuantan, Malaysia.

\section{MATERIALS AND METHODS}

This cross-sectional study employed the stratified random sampling method, which involved undergraduate students from six faculties, namely, Medicine, Dentistry, Allied Health Sciences, Nursing, Pharmacy and Sciences. A total of 316 subjects were selected into the study. Ethical approval was obtained from the International Islamic University Malaysia (IIUM) Research Ethics Committee. Consent from the participants was obtained prior to them answering the questionnaire.

A self-administered questionnaire was developed for this study. It was divided into five sections. The first section comprised the eight items of the USDA Adult Food Security Survey Module (USDAFSSM) which assesses the food security status of the subjects. The internal consistency (Cronbach's $\alpha$ ) of the questionnaire was 0.79 . The second section comprised items pertaining to the determinants of food insecurity, that included living arrangement and time constraints. In this section, the subjects were asked whether they felt that they had insufficient time to eat a balanced meal or even went hungry because of it. The third section gathered demographic information while the last section enquired about the spending patterns of the subjects. The questionnaire was piloted to evaluate the clarity, relevance and applicability of the questions. Data were analysed using Statistical Package for the Social Sciences version 12.0 (SPSS 12.0), which involved descriptive analysis and the chi-square test.

\section{RESULTS}

From the total of 316 samples selected, 307 completed the survey, making the

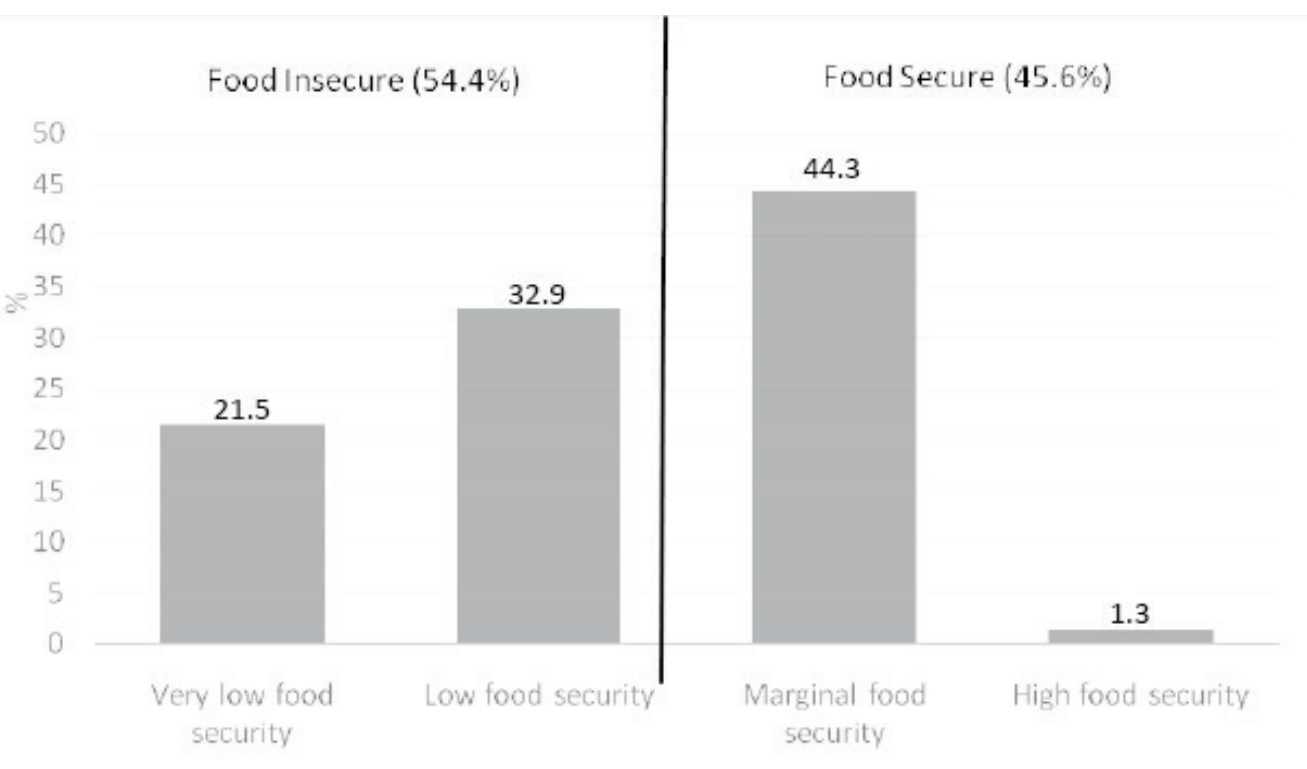

Figure 1. Food security status of the respondents 
Table 1. Demographic characteristics of the respondents

\begin{tabular}{lcc}
\hline Characteristics & $n$ & $\%$ \\
\hline Gender & 95 & 30.9 \\
$\quad$ Male & 212 & 69.1 \\
$\quad$ Female & 246 & 80.1 \\
Living arrangements & 53 & 17.3 \\
On-campus & 8 & 2.6 \\
Off-campus & & \\
With parents & 92 & 30.0 \\
Financial/loan sponsors & 132 & 43.0 \\
PTPTN (loans) & 8 & 2.6 \\
JPA (scholarships) & 28 & 9.1 \\
MARA (loans) & 47 & 15.3 \\
Others sponsors & & \\
Non-recipients of any kind of sponsorship & 172 & 56.0 \\
Source of income & 37 & 12.1 \\
Scholarship/Loan solely & 97 & 31.6 \\
Self-sponsored/Parents solely & 1 & 0.3 \\
$\quad$ Scholarship/Loan + Parents' support & & \\
Others/Part-time job &
\end{tabular}

response rate $97.0 \%$. Based on faculties, 107 (34.8\%) were from Sciences, 61 (19.9\%) Medicine, 53 (17.3\%) Pharmacy, $46(15.0 \%)$ Allied Health Sciences, 22 $(7.2 \%)$ Nursing and 18 (5.9\%) Dentistry. The majority of the students were females $(69.1 \%, n=212)$ and males were $30.9 \% \quad(n=95)$, proportions that reflect those of the general student body.

More than half of the students were food insecure giving a prevalence of $54.4 \% \quad(n=167)$. Of this proportion, $21.5 \% \quad(n=66)$ were placed into the category of very low food security and $32.9 \%(n=101)$ as low food security. For food secure category, marginal food security had largest percentage at $44.3 \%$ $(n=136)$ and only $1.3 \%(n=4)$ were highly food secure, as shown in Figure 1.

Many students in the current study received financial support. Overall, $84.7 \%$ $(n=260)$ were funded with scholarships

Table 2. Association of time constraint with food security status.

\begin{tabular}{|c|c|c|c|c|}
\hline \multirow[t]{2}{*}{ Description } & $\begin{array}{c}\text { Food } \\
\text { insecure }\end{array}$ & $\begin{array}{l}\text { Food } \\
\text { secure }\end{array}$ & \multirow{2}{*}{$\begin{array}{c}\text { Chi-square } \\
\text { statistics } \\
\text { (df) }\end{array}$} & \multirow[t]{2}{*}{$p$-value } \\
\hline & $\%$ & $n$ & & \\
\hline
\end{tabular}

"I couldn't eat balanced meals because I don't have much time to buy and eat the foods." How often did this happen to you in the last 6 months?

\begin{tabular}{lcccccc} 
Often true & 24 & 14.4 & 8 & 5.7 & 11.851 & 0.003 \\
Sometimes true & 104 & 62.3 & 78 & 55.7 & $(2)$ & \\
$\quad$ Never true & 39 & 23.4 & 54 & 38.6 & & \\
he last 6 months, were you ever & & & & & & \\
gry but didn't eat because there & & & & & & \\
n't enough time to eat? & 94 & 56.3 & 62 & 44.3 & 4.389 & 0.036 \\
$\quad$ Yes & 73 & 43.7 & 78 & 55.7 & $(1)$ & \\
No & & & & & & \\
\hline
\end{tabular}


Table 3. Expenses and food security status

\begin{tabular}{|c|c|c|c|c|c|c|}
\hline \multirow[t]{2}{*}{ Spending items } & \multicolumn{2}{|c|}{ Food insecure } & \multicolumn{2}{|c|}{ Food secure } & \multirow[t]{2}{*}{ Chi-square (df) } & \multirow[t]{2}{*}{$p$-value } \\
\hline & $n$ & $(\%)$ & $n$ & (\%) & & \\
\hline \multicolumn{7}{|l|}{ Weekly } \\
\hline \multicolumn{7}{|l|}{ Foods } \\
\hline$<$ RM 50 & 47 & $(28.1)$ & 41 & (29.3) & \multirow{2}{*}{$0.049(1)$} & \multirow{2}{*}{0.826} \\
\hline$>$ RM 50 & 120 & (71.9) & 99 & (70.7) & & \\
\hline \multicolumn{7}{|c|}{ Transportation } \\
\hline$<\mathrm{RM} 50$ & 133 & $(79.6)$ & 114 & $(81.4)$ & \multirow{2}{*}{$0.155(1)$} & \multirow{2}{*}{0.694} \\
\hline > RM 50 & 34 & $(20.4)$ & 26 & (18.6) & & \\
\hline \multicolumn{7}{|c|}{ Study material } \\
\hline$<$ RM 50 & 84 & $(50.3)$ & 84 & $(60.0)$ & \multirow{2}{*}{$2.892(1)$} & \multirow{2}{*}{0.089} \\
\hline > RM 50 & 83 & $(49.7)$ & 56 & $(40.0)$ & & \\
\hline \multicolumn{7}{|l|}{ Cell phone } \\
\hline$<$ RM 50 & 137 & $(82.0)$ & 114 & (81.4) & \multirow{2}{*}{$0.019(1)$} & \multirow{2}{*}{0.891} \\
\hline >RM 50 & 30 & $(18.0)$ & 26 & (18.6) & & \\
\hline \multicolumn{7}{|l|}{ Monthly } \\
\hline \multicolumn{7}{|l|}{ Shopping } \\
\hline$<$ RM 50 & 76 & $(45.5)$ & 57 & $(40.7)$ & \multirow{2}{*}{$0.713(1)$} & \multirow{2}{*}{0.398} \\
\hline > RM 50 & 91 & $(54.5)$ & 83 & (59.3) & & \\
\hline \multicolumn{7}{|c|}{ Housing / Hostel fees } \\
\hline$<$ RM 50 & 8 & $(4.8)$ & 3 & $(2.1)$ & \multirow{2}{*}{$1.545(1)$} & \multirow{2}{*}{0.214} \\
\hline$>$ RM 50 & 159 & (95.2) & 137 & (97.9) & & \\
\hline \multicolumn{7}{|c|}{ Entertainment } \\
\hline$<$ RM 50 & 121 & $(72.5)$ & 99 & (70.7) & \multirow{2}{*}{$0.114(1)$} & \multirow{2}{*}{0.736} \\
\hline$>$ RM 50 & 46 & $(27.5)$ & 41 & (29.3) & & \\
\hline \multicolumn{7}{|l|}{ Books* } \\
\hline$<$ RM 50 & 80 & $(47.9)$ & 89 & (63.6) & \multirow{2}{*}{$7.554(1)$} & \\
\hline$>$ RM 50 & 87 & $(52.1)$ & 51 & (36.4) & & 0.006 \\
\hline Miscellaneou & & & & & & \\
\hline$<$ RM 50 & 85 & (50.9) & 93 & $(66.4)$ & & \\
\hline > RM 50 & 82 & $(49.1)$ & 47 & (33.6) & $7.539(1)$ & 0.006 \\
\hline
\end{tabular}

or received study loan [National Higher Education Fund Corporation (PTPTN) study loans 30.0\%; Public Services Department (JPA) scholarships 43.0\%; Majlis Amanah Rakyat (MARA) study loans $2.6 \%$ \& other sponsors $9.1 \%]$ while another $15.3 \%(n=47)$ were selfsponsored. Further demographic characteristics are described in Table 1.

Table 2 shows the association of time constraints with food security status. More than half $(56.3 \%, n=94)$ of food insecure students agreed that time restriction caused them to skip meals even though they were hungry. However, a lower percentage $(44.3 \%, n=62)$ of food secure students did so for the same reason. A large percentage $(76.7 \%)$ of the food insecure students agreed that time constraints as the reason for them not to eat balanced meals, compared to $61.4 \%$ among the food secure group.

Table 3 shows the expenses of the students in the current study. The major expenses among both groups were mainly for housing rent or hostel fees. The next largest expense was food. The students spent about RM50 to RM150 on foods weekly. When they were asked to specify their miscellaneous expenses, 
Table 4. Demographic characteristics and food security status

\begin{tabular}{|c|c|c|c|c|c|c|}
\hline \multirow{2}{*}{ Demographic characteristics } & \multicolumn{2}{|c|}{ Food insecure } & \multicolumn{2}{|c|}{ Food secure } & \multirow{2}{*}{$\begin{array}{l}\text { Chi-square } \\
\text { statistics (df) }\end{array}$} & \multirow{2}{*}{ p-value } \\
\hline & $n$ & (\%) & $n$ & (\%) & & \\
\hline \multicolumn{7}{|l|}{ Gender } \\
\hline Male & 58 & $(34.7)$ & 37 & $(26.4)$ & \multirow[t]{2}{*}{$2.456(1)$} & \multirow[t]{2}{*}{0.117} \\
\hline Female & 109 & $(65.3)$ & 103 & $(73.6)$ & & \\
\hline \multicolumn{7}{|l|}{ Living arrangement } \\
\hline On-campus & 135 & $(80.8)$ & 111 & $(79.3)$ & \multirow[t]{3}{*}{$0.000(2)$} & \multirow[t]{3}{*}{0.983} \\
\hline Off-campus & 29 & $(17.4)$ & 24 & $(17.1)$ & & \\
\hline Own-house & 3 & $(1.8)$ & 5 & $(3.6)$ & & \\
\hline \multicolumn{7}{|l|}{ Faculty of study* } \\
\hline Medicine & 21 & (34.4) & 40 & (65.6) & \multirow[t]{6}{*}{$17.755(5)$} & \multirow[t]{6}{*}{0.003} \\
\hline Nursing & 15 & $(68.2)$ & 7 & $(31.8)$ & & \\
\hline Allied Health Sciences & 32 & (69.6) & 14 & $(30.4)$ & & \\
\hline Dentistry & 12 & $(66.7)$ & 6 & (33.3) & & \\
\hline Pharmacy & 26 & $(49.1)$ & 27 & $(50.9)$ & & \\
\hline Sciences & 61 & (57.0) & 46 & $(43.0)$ & & \\
\hline \multicolumn{7}{|l|}{ Parents income* } \\
\hline$<$ RM 1000 & 32 & (19.3) & 13 & $(9.4)$ & \multirow[t]{4}{*}{$18.641(3)$} & \multirow[t]{4}{*}{$<0.001$} \\
\hline RM1000-RM3000 & 43 & (25.9) & 42 & (30.4) & & \\
\hline RM3000-RM5000 & 53 & (31.9) & 26 & $(18.8)$ & & \\
\hline >RM5000 & 38 & (22.9) & 57 & (41.3) & & \\
\hline \multicolumn{7}{|l|}{ Scholarship type* } \\
\hline JPA & 61 & $(46.2)$ & 71 & $(53.8)$ & \multirow[t]{3}{*}{$15.423(2)$} & \multirow[t]{3}{*}{$<0.001$} \\
\hline PTPTN & 66 & (71.7) & 26 & (28.3) & & \\
\hline Others & 17 & $(47.2)$ & 19 & $(52.8)$ & & \\
\hline
\end{tabular}

${ }^{*} p<0.01$

most of them answered that they spent on supplements, medication, gadgets and broad-band internet access.

Table 4 addresses the relationship between some demographic characteristics of the respondents and their food security status. Significant association was found between food security status of the students with faculty of study, parents' income and scholarship type.

\section{DISCUSSION}

Majority of the students were found to be food insecure (54.4\%). Those in the food secure category were mainly marginally food secure $(44.3 \%)$ and only $1.3 \%$ were highly food secure. These findings are similar but slightly lower from what was reported by Sulaiman et al. (2013), who found that $67.1 \%$ of students from four universities in Malaysia were food insecure. Internationally, studies conducted in a midsize rural university in Oregon, and the University of Hawa'i at Manoa, both in the United States, reported that $59 \%$ and $45 \%$ of their students, respectively, were food insecure (Chaparro et al. 2009; Pattonlópez et al. 2014). This is an indicator that the students were facing financial and economic hardships up to a point that they may have compromised their food intake. Food insecurity can adversely affect health behaviour, including healthy eating habits and wellbeing, which subsequently influence 
academic performance (Bruening et al. 2018).

The majority of the students agreed that time constraint had caused them to face the feeling of hunger and not able to eat balanced meals. This sentiment was more prevalent among the food insecure group. It demonstrates that coping strategy for time management and meal pattern among students play a crucial role in determining student's food security status. This finding is in line with that reported by Abdullah \& Ali (2011) who explained that time management and financial problems played a crucial role in determining an individual's food intake. The study claimed that only $57.5 \%$ of students had meal at proper times while the rest did not take their meal at the appropriate times. The study further explained that improper meal times among students were caused by time and financial constraints which lead to restrictions on both expenses and irregular timetable, such as having 'brunch', the meal combination between breakfast and lunch. Even worse, when some of the students only had one meal per day often consuming unhealthy foods such as instant noodles or fast food. Abdullah \& Ali (2011) in their study also found that $61.5 \%$ of students spent $<$ RM10 per day for food in their daily expenditure, and the amount increased during weekends. This amount was low and not enough to have a healthy and balanced meal. However, this was not surprising because students were found to reduce their food expenditure in order to spend on other items such as their mobile phones, gadgets, computers and clothing.

Their financial situation is one of the factors that was consistently related to food insecurity among students (Bruening et al., 2017). In our study, the largest proportion of PTPTN loan recipients was among the students of the Allied Health Sciences programmes, which also had the largest percentage of food insecure students. In contrast, students of Medical faculty where majority were JPA scholarship recipients, were at the lowest rank of food insecurity. In other words, these students were better off compared to the others. This is because students with PTPTN loans received less funding compared to the JPA scholarship recipients. The incomes of parents were also found to correspond with food security status of the students. These factors clearly demonstrate that food security status of the students was affected by their financial situation.

Although it is uncommon for Malaysian students to have a part-time jobs to support their living cost, the trend is growing due to financial reason. The students at this university also had no access to appropriate food storage and preparation facilities on campus to prepare their own meals which may have helped to reduce their food cost. Relying on insufficient financial resources may be difficult for them to achieve food and nutrition security. The prevailing conditions make it difficult for them to achieve stability for all the main components of food security, namely accessibility to, availability and utilization of food.

\section{CONCLUSION}

A significant association was found between food security status with financial affordability, time constraint, scholarship types, academic programme and parents' income. This study ascertained that most of the students at this institution were experiencing or at risk of food insecurity. Thus, financial affordability and time management together with other factors found to be critical in this study may need further attention in order to improve food security among university students.

Food insecurity seems to be a significant problem among university students, which influence not just 
their wellbeing but also their academic performance. This study should be repeated at different institutions of higher learning around the country to better understand the issue and further strengthen the support system and introduce intervention programmes to improve access to adequate and nutritious foods for the student population. Hence, addressing food insecurity should be one of the priorities for university authorities and also relevant policy makers.

\section{Acknowledgement}

The investigators would like to thank the International Islamic University Malaysia (IIUM) Research Ethics Committee for approving the project and the participants of this study. This work was supported in-part by Ministry of Education research grant FRGS16-054-0553.

\section{Authors' contributions}

WAMAB, principal investigator, conceptualised and designed the study, prepared the draft of the manuscript and reviewed it; SI, undertook the data collection and analysis, and reviewed the manuscript; SS, reviewed the manuscript and advised on the data interpretation; RAR, provided advice on the data interpretation and reviewed and proofread the manuscript.

\section{Conflict of interest}

There is no conflict of interest to declare.

\section{References}

Abdullah MA \& Ali N (2011). Amalan pemakanan dalam kalangan pelajar universiti dan implikasinya terhadap pembelajaran. Jurnal Personalia Pelajar 14:59-68.

Adeyeye SAO (2017). The role of food processing and appropriate storage technologies in ensuring food security and food availability in Africa. Nutrition and Food Science 47(1):122139. https://doi.org/10.1108/NFS-03-20160037.

Alaimo K, Olson CM \& Frongillo EA (2002). Family food insufficiency, but not low family income, is positively associated with dysthymia and suicide symptoms in adolescents. The Journal of Nutrition 132(4):719-725. https://doi. org/10.1093/jn/132.4.719.

Alaimo K, Olson CM \& Frongillo EAJ (2001). Food insufficiency and American schoolaged children's cognitive, academic, and psychosocial development. Pediatrics 108(1):44 LP-53.
Bruening M, Argo K, Payne-Sturges D \& Laska MN (2017). The struggle is real: a systematic review of food insecurity on postsecondary education campuses. Journal of the Academy of Nutrition and Dietetics 117(11):1767-1791. https://doi. org/10.1016/j.jand.2017.05.022.

Bruening M, van Woerden I, Todd M \& Laska MN (2018). Hungry to learn: the prevalence and effects of food insecurity on health behaviors and outcomes over time among a diverse sample of university freshmen. International Journal of Behavioral Nutrition and Physical Activity 15(1):1-10. https://doi.org/10.1186/ s12966-018-0647-7.

Chaparro MPP, Zaghloul SS, Holck P \& Dobbs J (2009). Food insecurity prevalence among college students at the University of Hawai'i at Manoa. Public Health Nutrition 12(11):2097-2103. https://doi.org/10.1017/ S1368980009990735.

Che J \& Chen J (2001). Food insecurity in Canadian households. Health Reports / Statistics Canada, Canadian Centre for Health Information = Rapports Sur La Santé $/$ Statistique Canada, Centre Canadien d'information Sur La Santé 12(4):11-22. https://doi. org/10.1162/003465302317411587.

Cook JT, Frank DA, Berkowitz C, Black MM, Casey PH, Cutts DB, Meyers AF, Zaldivar N, Skalicky A, Levenson S, Heeren T \& Nord M (2004). Food insecurity is associated with adverse health outcomes among human infants and toddlers. The Journal of Nutrition 134(6):1432-1438. https://doi.org/10.1093/jn/134.6.1432.

Diette GB, Markson L, Skinner E, Nguyen TTH, Algatt-Bergstrom P \& Wu AW (2000). Nocturnal asthma in children affects school attendance, school performance, and parents' work attendance. Archives of Pediatrics \& Adolescent Medicine 154(9):923. https://doi. org/10.1001/archpedi.154.9.923.

IPH (2014). National Health and Morbidity Survey 2014: Malaysian Adult Nutrition Survey (MANS) Vol. 2. Institute for Public Health, Ministry of Health Malaysia. https:// doi.org/10.1017/ CBO9781107415324.004..

Ness AR, Maynard M, Frankel S, Smith GD, Frobisher C, Leary SD, Emmett PM \& Gunnell D (2005). Diet in childhood and adult cardiovascular and all cause mortality: The Boyd Orr cohort. Heart 91(7):894-898. https:/ / doi.org/10.1136/hrt.2004.043489.

Norhasmah S, Zalilah MS \& Asnarulkhadi AS (2010). Food Security: concepts and definitions. Journal of Community Health 16(2):2-9. 
Norhasmah S, Zalilah MS, Kandiah M, Mohd Nasir MT \& Asnarulkhadi AS (2012). Household food insecurity among urban welfare recipient households in hulu langat, selangor. Pertanika Journal of Social Science and Humanities 20(2):405-420.

Palmer D \& Groppo P (2002). Food Insecurity in the World 2002. FAO Report . https://doi.org/925-104328-0.

Pan L, Sherry B, Njai R \& Blanck HM (2012). Food insecurity is associated with obesity among US Adults in 12 States. Journal of the Academy of Nutrition and Dietetics 112(9):1403-1409. https://doi.org/10.1016/j.jand.2012.06.011.

Patton-lópez MM, López-Cevallos DF, CancelTirado DI, Vazquez L \& Patton-lópez MM (2014). Prevalence and correlates of food insecurity among students attending a midsize rural University in Oregon. Journal of Nutrition Education and Behavior 46(3):209-214. https://doi.org/10.1016/j.jneb.2013.10.007.

Ramsey R, Giskes K, Turrell G \& Gallegos D (2011). Food insecurity among Australian children: Potential determinants, health and developmental consequences. Journal of Child Health Care 15(4):401-416. https://doi. org/ $10.1177 / 1367493511423854$.

Roselawati MY, Wan Azdie MAB, Aflah A, Jamaludin AR \& Zalilah MS (2017). Food security status and childhood obesity in Kuantan Pahang. International Journal of Allied Health Sciences $1(2): 56-71$.
ShariffZM \& Khor GL (2005). Obesity and household food insecurity: evidence from a sample of rural households in Malaysia. European Journal of Clinical Nutrition 59:1049-1058. https://doi. org/10.1038/sj.ejcn.1602210.

Sulaiman N, Md Jusoh Z \& Ab Razak M (2013). Food insecurity among public university students receiving financial assistance in Peninsular Malaysia. Malaysian Journal of Consumer and Family Economics 16:78-90.

United Nations (1975). Report of the World Food Conference, Rome 5-16 November 1974. In World Food Conference.

Van Der Pols JC, Gunnell D, Williams GM, Holly JMP, Bain C \& Martin RM (2009). Childhood dairy and calcium intake and cardiovascular mortality in adulthood: 65-Year follow-up of the Boyd Orr cohort. Heart 95(19):1600-1606. https://doi.org/10.1136/hrt.2009.168716.

Vozoris NT \& Tarasuk VS (2003). Household food insufficiency is associated with poorer health. The Journal of Nutrition 133(1):120-126.

Wright CM, Parker L, Lamont D \& Craft AW (2001). Implications of childhood obesity for adult health: findings from thousand families cohort study. British Medical Journal 323(7324):1280-1284. https://doi. org/10.1136/bmj.323.7324.1280. 